\title{
A COMPARATIVE ASSESSMENT OF SMALL SCALE POULTRY EGG PRODUCTION SYSTEM IN OSUN STATE, NIGERIA.
}

\author{
${ }^{1}$ Akinyemi, Mudashiru, ${ }^{1}$ Ekpa, Daniel and ${ }^{2}$ Adeosun, Stella Laruba \\ ${ }^{1}$ Department of Agricultural Economics, Federal University Dutsin-Ma, Katsina State, Nigeria. \\ ${ }^{2}$ Department of Animal Science, Federal University Dutsin-Ma, Katsina State, Nigeria.
}

http://doi.org/10.35410/IJAEB.2019.4405

\begin{abstract}
The study examined the comparative study of Poultry Production System in Osun State, Nigeria. Primary data from a cross-section of 100 poultry egg farmers were used ( 45 deep litter and 55 batery cage farms)The study employed a multi-stage sampling techniques for the selection of respondents. The data were collected by means of structured questionaire and analysed using descriptive statistics and budgetary analysis. The average age of the deep litter farmers was found to be 37 years while those of the battery cage was 42 years. Egg production from both production system was male dominated with $81.2 \%$ in deep litter and $87.40 \%$ in battery cage.The average farming experience of the deep litter farmers was $15 y e a r s$ while that of the battery cage was 10 years. From the budgetary analysis it was discovered that the rate of return to investment for deep litter farmers was $13.96 \%$ as against $17.07 \%$ in battery cage system. This shows that battery cage production system were more profitable than deep litter system. This shows that for battery cage production system $\mathrm{N} 1$ invested in egg enterprise would give a return of N1.71 and N1.40 for battery cage and deep litter production system respectively.The study concluded that battery cage production system was more profitable than deep litter production system. It recommends that Poultry farmers should organise themselves in groups to facilitate fund assessment from the financial institution. Government should encourage the use of battery cage production system through local fabrication of cheap and affordable cage equipment .Government should enhance the capacity building of farmers though their professional association.
\end{abstract}

Keywords: Small-Scale, Poultry-Egg, Production-System, Osun-State, Nigeria.

\section{INTRODUCTION}

The significant contribution of livestock sub-sector to Nigerian economy cannot be over emphasized. Over the decades livestock had made a major impact to national output by generating employment through agricultural value-addition thereby contributing immensely to national Gross Domestic Product (GDP). In 1960, the subsector contributed about 5.61\% representing N139.6 million of the GDP. The other agricultural sub sectors such as crop, forestry and fisheries had a share of $58.67 \%$ totaling N1460.2million. Thus, Agriculture accounted for nearly 64.28\% of the GDP in 1960.The contributions of livestock to Agriculture in 1999 and 2010 remain at 2.64\% (CBN,2008, 2009, 2010 and FAOSTAT,2010) 
However, the contribution of poultry production (meat and eggs) to total livestock output increased from $26 \%$ in 1995 to $27 \%$ in 1999 with an increase in egg production alone accounting for about $13 \%$ during the period. (Ojo 2003).

The poultry sub-sector is an imperative avenue in promoting agricultural growth and reduce malnutrition for the people in Nigeria. This sub-sector has proved as an attractive economic activity, thereby, indicating its`importance for the entire economy. It provides direct animal protein and also improving the purchasing power of the households to be able to grow enough food or purchase food from the market. Poultry manure is used as a supplement in dairy cattle production and complemented crop production

Tijani et. al,(2006) found out in their study that the quality of food consumed by households affect their health and economic well-being. This in turn has significant repercussions on the general level of economic activities and productivity.

Acute protein shortage is evident in the diet of many Nigerians especially in the rural areas, where over $70 \%$ of the Nigerian population reside. Yusuf and Malomo (2007) observed that, the nutritional value of food consumed by an average Nigerian household is below the recommended standard of protein intake from poultry sources. The average daily protein intake of urban people is estimated to be 28 grams per caput. In the rural area, this was found to be 17 grams per caput. In both cases, it falls below the Food and Agriculture Organization (FAO) recommendation of 35 grams daily intake of animal protein (Akanni, 2007)

The inherent economic potential in both deep litter and battery cage systems of production is of relevance in an attempt at increasing egg production in Nigeria. Majority of egg producers use the battery cage system. This requires enormous capital outlay to operate. According to Ajibefun et. al (2002) the deep liter system offers greater economic returns. It reduces environmental discharge, decreases cost of operation and increases laying periods, in comparison with battery cage system. (Rahji et al 2015)

In order to promote a more balanced economic growth, something urgent must be done to boost animal protein production. Therefore, this study intends to give answer to the reason for the profit differential in the poultry egg production system by comparing the profit efficiency estimates of egg production systems in the study area

\section{METHODOLOGY}

The study area is Osun state. The state consists of thirty (30) Local Government Areas. It covers an area of approximately $14,875 \mathrm{sq} \mathrm{km}$ and lies between latitude $70^{\circ} 28^{\prime} \mathrm{N}$ and longitude $40^{\circ}$ $34^{\prime}$ E with the mean annual rainfall of $900 \mathrm{~mm}$. Agriculture is the main source of livelihood of the people in the state. Off-farm activities include trading, blacksmithing, tailoring, weaving, dryseason fishing, hunting among others. Farming practices used in the states include shifting cultivation, mixed farming, mixed cropping and pastoral farming. The climate makes the farmers to cultivate a very wide range of crops such as cassava, yam, tobacco, cotton, maize and vegetable. Tree crops such as cocoa, oil palm, kola nut, citrus etc. are also produced. Livestock such as cattle, goats, sheep, pigs and poultry such as chicken, turkey, pigeon, ostriches and duck 
etc are produced. The livestock are reared extensively. Intensive livestock production is expensive. The predominant breed of poultry birds kept in the zone include broiler like Anak 2000 and Asoika. While, layers include; Black race, Brown yaffa and White leghorn, Cockerels include black Hacco, white Leghorn. Primary data used for this study was collected by means of structured questionnaire from poultry egg farmers. These farmers practised both deep litter and battery cage systems of egg production in Osun States. For the purpose of this study, comprehensive lists of poultry farms operating in each Poultry Association zones were obtained from the administrative Office of PAN in Oshogbo city in Osun states. This constitutes the sampling frame for the study. The questionnaires were administered with the assistance of administrative staff of PAN in Osun states

Data were collected on socioeconomic characteristics such as age, gender, marital status, educational status, production system, credit access and household variables. In addition, output and prices of egg, quantities and prices of inputs such as labour, drugs, day old chicks and feeds and total revenue were elicited from the respondents.

Information on access to cooperative loan, sources of funds for farming and difficulty encountered during egg production for 2009/2010 farming season were also obtained.

A multistage sampling technique was employed for the collection of data from the poultry egg farmers (practicing both deep litter and battery cage systems in Osun state). The first stage involved a random selection of three poultry association zones (Oshogbo, Ikirun and Ibokun) from five existing poultry association zone (Ife, Ikire, Oshogbo, Ikirun and Ibokun) in the state. The second stage involved a stratification of the poultry farmers into battery cage and deep litter production system. The last stage involved a random selection of poultry farmers from the two production systems across the states. Based on stratification of the farmers 12 poultry farmers using deep litter in Oshogbo zone, 17 in Ikirun zone and 16 in Ibokun zone were randomly selected using proportionate formular. In addition, to these, 21 farmers using battery cage system in ibokun zone, 12 in Ikirun zone and 22 in Osun State were randomly sampled.Table. 1

Table 1 Sampling Frame and Sampling Size for the Study

\begin{tabular}{|l|l|l|l|l|}
\hline \multirow{2}{*}{ PAN Zone } & \multicolumn{2}{|c|}{ Sample Frame } & \multicolumn{2}{c|}{ Sample Size } \\
\cline { 2 - 5 } & Deep Litter & Battery Cage & Deep Litter & Battery Cage \\
\hline Oshogbo & 21 & 40 & 12 & 22 \\
\hline Ikirun & 29 & 24 & 17 & 12 \\
\hline Ibokun & 28 & 39 & 16 & 21 \\
\hline Total & 78 & 103 & 45 & 55 \\
\hline
\end{tabular}

Source: Field Survey 2013

3 METHODS OF DATA ANALYSIS 
Descriptive statistics such as frequency and percentages were used to analyze the socioeconomic characteristics of poultry egg farmers covering age, religion, sex, education, farming experience, gender, household size and credit access

Budgetary Analysis (Profitability Analysis). To determine the profitability of poultry egg production in Osun state, the gross margin was calculated which is the difference between the total revenue and the total variable cost.

The mathematical notation for calculating the gross margin is given by the equation below

$\mathrm{GM}=\mathrm{P}_{\mathrm{i}} \mathrm{Y}_{\mathrm{i}}-\mathrm{r}_{\mathrm{i}} \mathrm{c}_{\mathrm{i}}$

Where;

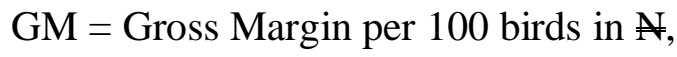

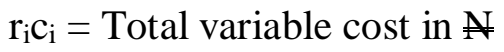

$\mathrm{P}_{\mathrm{i}} \mathrm{Y}_{\mathrm{i}}=$ Total revenue in Farm gate price of the egg in crate in $\mathrm{N}$,

$\mathrm{P}_{\mathrm{i}}=$ farm gate price of the $\mathrm{i}^{\text {th }}$ egg in crate in $\mathrm{N}$

$Y_{i}=$ Output of the $i^{\text {th }}$ farm producing $i^{\text {th }}$ egg

$\mathrm{r}_{\mathrm{i}}=$ Price of the $\mathrm{i}^{\text {th }}$ variable input

$\mathrm{C}_{\mathrm{i}}=$ Quantity of $\mathrm{i}^{\text {th }}$ variable input

The total revenue, total cost, Rate of return to investment (RROI), and Rate of return on fixed Cost (RRFC) were also calculated using the formula below

$$
\begin{aligned}
\text { RORI } & =\frac{\text { Profit }}{\text { TotalCost }} * 100 \\
\text { RORI } & =\frac{\text { Profit }}{\text { TotalCost }} * 100
\end{aligned}
$$

Total Revenue (TR)

$\mathrm{TR}=Y_{1}+Y_{2}+Y_{1}$

$Y_{1}=$ Revenuefromthesalesof $\mathrm{gg} g$

$\mathrm{Y}_{2}=$ Revenue from the Spent layer $(\mathrm{N})$

$\mathrm{Y}_{3}=$ Revenue from the sales of unused bags and litter (N) 
Total Variable Cost (TVC)

$\mathrm{TVC}=X_{1}+X_{2}+X_{2}+X_{4}+X_{5}+X_{6}+X_{7}+X_{2}$

Where;

$$
\begin{aligned}
& x_{1} \quad \text { CostofStockProcurement } \\
& x_{2} \quad=\text { CostofFeeds } \\
& x_{1} \quad=\text { Costof ferterinaryServices } \\
& x_{4} \quad=\text { CostofLabour } \\
& x_{5} \quad=\text { CostofWater } \\
& x_{6} \quad=\text { CostofEnergy } \\
& x_{7} \quad=\text { CostofTransport } \\
& x_{9} \quad=\text { OtherVariableCost }
\end{aligned}
$$

Profit $=$ Gross margin - Total fixed cost

Total cost $=$ Fixed cost + Variable Cost

To obtain the worth of each of the fixed cost items the straight-line method of depreciation was used and it was assumed that the salvage value of the fixed items used in the egg production is zero the formula for depreciation using straight-line method is given as:

Depreciation $=\frac{\text { PurchasePrice }}{\text { Noofyearsof theusef ullifeof theassets }}$

Total Fixed Cost (TFC)

$Z_{1}+Z_{2}+Z_{9}+Z_{4}+Z_{5}+Z_{6}+Z_{7}+Z_{9}+Z_{9}$

Where:

$Z_{1} \quad=$ Depreciationonbuilding

$Z_{2} \quad=$ DepreciationonCages

$Z_{\mathrm{a}} \quad=$ DepreciationonFeeders

$Z_{4} \quad=$ DepreciationonGenerator

$Z_{5} \quad=$ DepreciationonPumpingMachine

$Z_{6} \quad=$ DepreciationonWaterTank 


$$
\begin{aligned}
& z_{7} \quad=\text { DepreciationonDrinkers } \\
& z_{g} \quad=\text { DepreciationonDebeaker } \\
& z_{9}=\text { InterestonCapital }(\cong)
\end{aligned}
$$

\section{RESULT AND DISCUSSION}

The results of the descriptive statistics of the farmers covering their age, gender, level of education, farming experience, household size and access to credit are presented in Table 2 below. The average age of the farmers was estimated to be 37 years for the deep litter farmers and 42 years for the battery cage farmers. According to Rahji et al (2015) these age classes fall within the active productive young people. They are characterized by natural strength, wisdom and other virtues which when employed can be used to transform egg industry in Osun state and Nigeria at large.

The education level of the sampled farmers shows that, the majority of small-scale deep litter farmers (40\%) in Osun State were graduate, 28.89\% had secondary school and about 22.22\% had post graduate. The same trend is applicable among the battery cage farmers, $47.27 \%$ were graduate, $21.82 \%$ had secondary school education, $16.36 \%$ had primary education and $14.55 \%$ had post graduate education. This level of education may influence technology adoption and skill acquisition. This may consequently increase production of poultry egg. This is because such is needed to acquire Knowledge about the latest research efforts in egg production and poultry health management. This would also aid in the prevention of communicable diseases such as avian influenza and to increased productivity of the farmers. The farming experience of the deep litter farmers reveals that majority $51.11 \%$ had experience between $11-15$ years, $24.45 \%$ had experience between 6-10 years and $17.78 \%$ had more than 15 years experience. The battery cage farmers shows that majority (49.09) had between 6-10 years farming experience,38.88\% had between 11-15years and about $3.64 \%$ had more than 15years of farming experience.

The result also shows that males are more involved in poultry egg production than female. In the deep litter production system the males were found to be $81.20 \%$ and for the battery cage males were $87.40 \%$. The result showed that females are less involved in egg production in the study area. The reason for the less involvement of female in egg production is the assumption that female farmers are less efficient in poultry farming than male farmers. (Bamiro, 2017)

In sourcing credit, $35.55 \%$ of deep litter farmers sourced credit from cooperatives, $28.89 \%$ used the credit from personal savings. Those who got theirs from the bank loans were $15.6 \%$ while about $20 \%$ got their credit from other sources such as gift, borrowing and proceeds from previous farming. On the other hand, 29.09\% of battery cage farmers got their credit from cooperatives, $25.45 \%$ got theirs from the bank, $23.64 \%$ used personal savings and $21.82 \%$ got their credit from other source.

The household size distribution reveals that majority of deep litter farmers $(31.11 \%)$ had between 6-10 household size and $26.67 \%$ had between $16-20$ household size and $24.44 \%$ had between $1-5$ 
household size. The house hold size of battery cage farmers shows that majority (36.36\%) had between 11-15 members, $29.04 \%$ had between 16-20 members and about $21.82 \%$ had between 1-5 household size while $3.64 \%$ had more than 20 household members. This was not expected despite the level of education of the poultry farmers in the study area. The result is however in consonance with the findings of Sarah et al 2016 who found out that more than 570 million farms in sub-Saharan Africa are small and family-run. Generally, the household size characterized the traditional agriculture in sub-Saharan Africa. The household size tends to support farming activities by supplementing the hired labour thereby enhances farming household productivity.

Table 2 Socio Economic Characteristic of the Respondents

\begin{tabular}{|l|l|l|l|l|}
\hline \multirow{2}{*}{ Range } & \multicolumn{2}{|l|}{ Deep Litter System } & \multicolumn{2}{c|}{ Battery Cage System } \\
\cline { 2 - 5 } \multicolumn{1}{|c|}{ Age } & Frequency & Percentage & Frequency & Percentage \\
\hline $21-30$ & 06 & & & \\
\hline $31-40$ & 18 & 13.03 & 11 & 20.00 \\
\hline $41-50$ & 13 & 40.00 & 21 & 38.18 \\
\hline $51-60$ & 05 & 28.89 & 12 & 21.82 \\
\hline $61 \&$ above & 03 & 11.14 & 04 & 07.27 \\
\hline Total & 45 & 06.67 & 07 & 12.73 \\
\hline Average & & 100.00 & 55 & 100 \\
\hline Gender & & 37 & & 42 \\
\hline Male & 37 & & & 87.40 \\
\hline Female & 08 & 81.20 & 48 & 12.60 \\
\hline Total & 45 & 18.80 & 07 & 100.00 \\
\hline Religion Affliation & & 100.00 & 55 & 32.73 \\
\hline Christian & 29 & & 64.18 \\
\hline Muslim & 12 & 26.67 & 18 & 09.09 \\
\hline Traditional & 04 & 08.89 & 05 & \\
\hline
\end{tabular}


Vol. 4, No. 04; 2019

ISSN: $2456-8643$

\begin{tabular}{|c|c|c|c|c|}
\hline Total & 45 & 100.00 & 55 & 100.00 \\
\hline \multicolumn{5}{|c|}{ Educational Level } \\
\hline Primary & 04 & 8.89 & 09 & 16.36 \\
\hline Secondary & 13 & 28.89 & 12 & 21.82 \\
\hline University & 18 & 40 & 26 & 47.27 \\
\hline Post graduate & 10 & 22.22 & 08 & 14.55 \\
\hline Total & 45 & 100.00 & 55 & 100.00 \\
\hline \multicolumn{5}{|c|}{$\begin{array}{l}\text { Farming Experience } \\
\text { (years) }\end{array}$} \\
\hline $1-5$ & 03 & 6.67 & 05 & 9.09 \\
\hline $6-10$ & 11 & 24.44 & 27 & 49.09 \\
\hline $11-15$ & 23 & 51.11 & 21 & 38.18 \\
\hline Greater than 15 & 08 & 17.78 & 02 & 3.64 \\
\hline Total & 45 & 100.00 & 55 & 100.00 \\
\hline \multicolumn{5}{|l|}{ Credit Source } \\
\hline Bank & 07 & 15.56 & 14 & 25.45 \\
\hline Cooperative & 16 & 35.55 & 16 & 29.09 \\
\hline Personal Savings & 13 & 28.89 & 13 & 23.64 \\
\hline Others & 09 & 20 & 12 & 21.82 \\
\hline Total & 45 & 100 & 55 & 100 \\
\hline \multicolumn{5}{|l|}{ Household Size } \\
\hline $1-5$ & 11 & 24.44 & 12 & 21.82 \\
\hline $6-10$ & 14 & 31.11 & 05 & 09.09 \\
\hline $11-15$ & 08 & 17.78 & 20 & 36.36 \\
\hline $16-20$ & 12 & 26.67 & 16 & 29.09 \\
\hline
\end{tabular}




\begin{tabular}{|l|l|l|l|l|}
\hline Greater than 20 & 00 & 00.00 & 02 & 03.64 \\
\hline Total & 45 & 100 & 55 & 100 \\
\hline
\end{tabular}

Source: Field Survey 2013

\section{Cost and Return Structure of Production System}

Assessment of the costs and returns shows that the average battery cage farmer in Osun State spent $61.51 \%$ of their operating cost on feed, $7.58 \%$ on labour, $3.27 \%$ on stock procurement and 9.97 on drugs. On the other hand, deep litter farmers spent $65.18 \%$ of their operating cost on feed, $9.88 \%$ on labour, $2.17 \%$ on stock procurement and 7.99 on drugs.

The profitability analysis of deep litter farmers in Osun States reveals that the average deep litter farmers spent more on feeds compared with the cage farmers. This shows the difficulty encountered by the farmers in getting cheap poultry feed materials. Majority of the farmers in Osun State are cash crop farmers. The maize farmers operate subsidence farming; poultry farming in the State depends on northern supply and neighboring States for the milling of feed ingredients. The farmers in both production systems spent more on drugs. This might have negative effect on the profitability of egg in the States.

From table 3 , the profitability indicators revealed that the rate of return to investment of poultry egg farmers varies in both the production systems. The battery cage system have the highest values of rate of return to investment (RROI) of $17.07 \%$ as against the deep litter farmers with. $13.96 \%$. This implies that, for every naira invested by the battery cage and deep litter farmer, there is a return on investment of $\$ 1.71$ and $\$ 1.40$ respectively.

The rate of returns to investment and rate of returns to fixed capital values for battery cage farmers in Osun state were higher compared with deep litter farmer. This means that battery cage farmers are more profitable than deep litter farmers. The reason from the results is obvious; battery cage farmers were able to have lower operating cost this consequently increase their profit

Table 3: Rate of Return (RORI) Estimates of the Two Production Systems

\begin{tabular}{|l|l|l|l|}
\hline DESCRIPTION & $\begin{array}{l}\text { BATTERY CAGE } \\
\text { SYSTEM }\end{array}$ & DEEP LITTER SYSTEM \\
\hline & INCOME & $\left({ }^{\prime} 000 \mathrm{~N}\right)$ & $\left({ }^{\prime} 000 \mathrm{~N}\right)$ \\
\hline & Egg Revenue & 2891.97 & 1337.75 \\
\hline & Spent Layer & 360.00 & 220.15 \\
\hline & Bags and Litter & 5.64 & 9.43 \\
\hline & Total Revenue & 3257.61 & 1567.33 \\
\hline & COST & & \\
\hline & Stock Procurement & 83.56 & 52.44 \\
\hline & Feed & 1574.25 & 809.91 \\
\hline
\end{tabular}




\begin{tabular}{|l|l|l|l|}
\hline & Veterinary & 255.15 & 99.26 \\
\hline Labour & 193.91 & 135.90 \\
\hline & Water & 87.19 & 40.99 \\
\hline & Energy & 154.04 & 50.45 \\
\hline & Transport & 103.97 & 26.11 \\
\hline Operating Variable Cost(OVC) & 106.93 & 9.76 \\
\hline & Total Variable Cost (TVC) & 2558.99 & 12424.81 \\
\hline & Total Fixed Cost (TFC) & 223.62 & 150.52 \\
\hline & Total Cost & 2782.62 & 1375.34 \\
\hline & Gross Margin & 528.01 & 281.86 \\
\hline & Profit & 474.99 & 191.99 \\
\hline & Rate of Return on Investment(ROI) & 17.07 & 13.96 \\
\hline & Rate of Return on Fixed Cost(RRC) & 236.12 & 168.38 \\
\hline & Average Farm Size & 528 & 336 \\
\hline
\end{tabular}

Source: Field Survey 2013

\section{CONCLUSION AND RECOMMENDATION}

Small Scale Poultry egg farming in Osun state is very profitable. The farmers are relatively young and the farming environment for poultry egg farming is dynamic and attractive. Therefore, prospects abounds in the state to expand poultry industry, take poultry farmers to greater heights and also reinforce the poultry industry to enviable position

The study recommends that Poultry farmers should be organized into more functional groups to facilitate fund assessment from the financial institution and solve common problems that might be imposing threats to the survival of small scale poultry farming in the state. Government should encourage the use of battery cage production system through local fabrication of cheap and affordable cage equipment. Government and all the stakeholders should enhance the capacity building of poultry farmers though their professional association.

\section{REFERENCE}

Ajibefun, I.A, G.E. Battese and A.G Daramola (2002): "Determinants of Technical Efficiency in Smallholder Food Crop Farming: Application of Stochastic Fronter Production Function". Quartely Journal of intergrated Agriculture 41 (5) 225-240.

Akanni K. A. (2007): "Effect of Micro-Finance on Small Scale Poultry Business in South western Nigeria". Emirate Journal of Food andAgriculture.19 (2): 38-47 http://www.cfa.uaeu.ac.ae

CBN (2010): Central Bank of Nigeria. Annual Report .Statement of Account

FAOSTAT (2010) : Statistical Data base of Food and Agricultural Organization of the United Nations, Rome, Italy. http// faosta.fao.org 
Food and Agricultural Organization (2010):.Food Supply Situation and Crop Prospects in SubSaharan Africa. FAO Global Information and Early Warning Systems (GIE WS) Africa report no. 1 http://faodoc.org/docrep/006.

Ojo, S.O. (2003): "Productivity and Technical Efficiency of Poultry Egg Production in Nigeria". International Journal of Poultry Science, 2 (3): 459- 464.

Rahji, M.A.Y., Akinyemi, M. and D.G. Akun, D.G.( 2015): Farm Size and Relative Efficiency in Egg Production in South-Western Nigeria: A Normalized Profit Function Approach. Scholarly Journal of Agricultural Science 5 (4), 141-146

Rahman S.A (2004): Analysis of egg production, distribution and consumption in parts of Nassarawa State, Nigeria. Research Journal of Agriculture and Biological Sciences, 4(1): 2539.

Tijani A.A., T.Alimi and A.T. Adesiyan (2006):"Profit Efficiency among Nigerian Poultry Egg Farmers: A Case Study of Aiyetoro Farm Settlement".Nigeria. Research Journal of Agricultural Biological Sciences, 2(6): $\quad 256-261,2006$

Yusuf, S.A and O. Malomo (2007): "Technical efficiency of Poultry Egg Production in Ogun State : A Data Envelopment Analysis (DEA) Approach", International Journal of Poultry Science. 6(9); 122-129. 